\title{
Concentrations of IGF-I and IGFBP-3 and pancreatic cancer risk in the European Prospective Investigation into Cancer and Nutrition
}

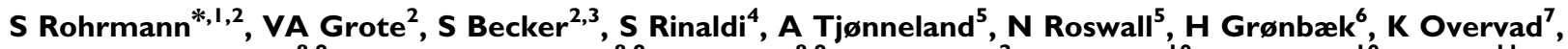
MC Boutron-Ruault ${ }^{8,9}$, F Clavel-Chapelon ${ }^{8,9}$, A Racine ${ }^{8,9}$, B Teucher $^{2}$, H Boeing ${ }^{10}$, D Drogan ${ }^{10}, V$ Dilis $^{11}$, P Lagiou' ${ }^{12,13,14}$, A Trichopoulou ${ }^{11,12}$, D Palli ${ }^{15}$, G Tagliabue ${ }^{16}$, R Tumino ${ }^{17}$, P Vineis ${ }^{18,19}$, A Mattiello ${ }^{20}$, L Rodríguez $^{21}$, EJ Duell ${ }^{22}$, E Molina-Montes ${ }^{23,24}$, M Dorronsoro ${ }^{25}$, J-M Huerta ${ }^{26,24}$, E Ardanaz ${ }^{27,24}$, Jeurnink $^{28,29}$, PHM Peeters $^{30}$, B Lindkvist ${ }^{31}$, D Johansen ${ }^{32}, M_{\text {Sund }}^{33}$, W Ye ${ }^{34,35}$, K-T Khaw ${ }^{36}$, NJ Wareham ${ }^{37}$, NE Allen ${ }^{38}$, FL Crowe $^{38}$, V Fedirko ${ }^{4}, M$ Jenab ${ }^{4}$, DS Michaud ${ }^{18,39}$, T Norat ${ }^{18}$, E Riboli ${ }^{18}$, HB Bueno-de-Mesquita ${ }^{28,29}$ and R Kaaks $^{2}$

'Division of Cancer Epidemiology and Prevention, Institute of Social and Preventive Medicine, University of Zurich, Hirschengraben 84, Zürich 800 I, Switzerland; ${ }^{2}$ Division of Cancer Epidemiology, German Cancer Research Center (DKFZ), Heidelberg, Germany; ${ }^{3}$ Institute of Laboratory Medicine, Clinical Chemistry and Molecular Diagnostics, University Hospital Leipzig, Leipzig, Germany; ${ }^{4}$ International Agency for Research on Cancer (IARC-WHO), Lyon, France; ${ }^{5}$ Diet, Cancer and Health, Danish Cancer Society, Copenhagen, Denmark; ${ }^{6}$ Department of Medicine V, Aarhus University Hospital, Aarhus, Denmark; ${ }^{7}$ Department of Epidemiology, School of Public Health, Aarhus University, Aarhus, Denmark; ${ }^{8}$ Inserm, Centre for Research in Epidemiology and Population Health, Institut Gustave Roussy, Villejuif, France; ${ }^{9}$ Paris South University, Villejuif, France; ${ }^{10}$ Department of Epidemiology, German Institute of Human Nutrition, Nuthetal, Germany; "Hellenic Health Foundation, Athens, Greece; ${ }^{12}$ WHO Collaborating Centre for Food and Nutrition Policies, Department of Hygiene, Epidemiology and Medical Statistics, University of Athens Medical School, Athens, Greece; '13 Bureau of Epidemiologic Research, Academy of Athens, Athens, Greece; ${ }^{14}$ Department of Epidemiology, Harvard School of Public Health, Boston, MA, USA; ${ }^{15}$ Molecular and Nutritional Epidemiology Unit, Cancer Research and Prevention Institute (ISPO). Florence, Italy; ${ }^{16}$ Lombardy Cancer Registry and Environmental Epidemiology Unit, Fondazione IRCCS Istituto Nazionale dei Tumori, Milan, Italy; ${ }^{17}$ Cancer Registry and Histopathology Unit, 'Civile M.P. Arezzo' Hospital, Ragusa, Italy; ${ }^{18} \mathrm{~S}$ chool of Public Health, Imperial College London, London, UK; ${ }^{19} \mathrm{HuGeF}$ Foundation, Torino, Italy; ${ }^{20}$ Department of Clinical and Experimental Medicine, Federico II University, Naples, Italy; ${ }^{21}$ Public Health and Participation Directorate, Health and Health Care Senvices Council, Asturias, Spain; ${ }^{22}$ Unit of Nutrition, Environment and Cancer, Catalan Institute of Oncology (ICO-IDIBELL), Barcelona, Spain; ${ }^{23}$ Andalusian School of Public Health, Granada, Spain; ${ }^{24}$ Consortium for Biomedical Research in Epidemiology and Public Health (CIBER) de Epidemiología y Salud Pública (CIBERESP), Spain; ${ }^{25}$ Epidemiology and Health Information, Public Health Division of Gipuzkoa, Basque Regional Health Department, San Sebastian, Spain; ${ }^{26}$ Department of Epidemiology, Murcia Regional Health Authority, Murcia, Spain; ${ }^{27}$ Navarre Public Health Institute, Pamplona, Spain; ${ }^{28}$ National Institute for Public Health and Environment (RIVM), Bilthoven, The Netherlands; ${ }^{29}$ Department of Gastroenterology and Hepatology, University Medical Centre Utrecht (UMCU), Utrecht, The Netherlands; ${ }^{30}$ Julius Center, University Medical Center Utrecht, Utrecht, The Netherlands; ${ }^{31}$ Institute of Medicine, Sahlgrenska Academy, University of Gothenburg, Gothenburg, Sweden; ${ }^{32}$ Department of Surgery, Skåne University Hospital, SUS, Malmö, Sweden; ${ }^{33}$ Departments of Surgical and Perioperative Sciences, Surgery and Public Health and Clinical Medicine, Nutrition Research, Umeå University, Umeå, Sweden; ${ }^{34}$ Department of Medical Epidemiology and Biostatistics, Karolinska Institutet, Stockholm, Sweden; ${ }^{35}$ The Medical Biobank at Umeå University, Umeå, Sweden; ${ }^{36}$ Department of Public Health and Primary Care, University of Cambridge, Cambridge, UK; ${ }^{37}$ Medical Research Council (MRC) Epidemiology Unit, Cambridge, UK; ${ }^{38}$ Cancer Epidemiology Unit, Nuffield Department of Clinical Medicine, University of Oxford, Oxford, UK; ${ }^{39}$ Department of Epidemiology, Division of Biology and Medicine, Brown University, Providence, RI, USA
\end{abstract}

BACKGROUND: Insulin-like growth factors (IGFs) and their binding proteins (BPs) regulate cell differentiation, proliferation and apoptosis, and may have a role in the aetiology of various cancers. Information on their role in pancreatic cancer is limited and was examined here in a case-control study nested within the European Prospective Investigation into Cancer and Nutrition. METHODS: Serum concentrations of IGF-I and IGFBP-3 were measured using enzyme-linked immunosorbent assays in 422 cases and 422 controls matched on age, sex, study centre, recruitment date, and time since last meal. Conditional logistic regression was used to compute odds ratios (OR) and $95 \%$ confidence intervals $(\mathrm{Cl})$ adjusted for confounding variables.

RESULTS: Neither circulating levels of IGF-I (OR = I.21, 95\% Cl 0.75- 1.93 for top vs bottom quartile, $P$-trend 0.30I), IGFBP-3 (OR = I.00, 95\% Cl 0.66- I.5I, P-trend 0.79), nor the molar IGF-I/IGFBP-3 ratio, an indicator of free IGF-I level (OR= I.22, 95\% Cl 0.75-1.97, P-trend 0.27), were statistically significantly associated with the risk of pancreatic cancer. In a cross-classification, however, a high concentration of IGF-I with concurrently low levels of IGFBP-3 was related to an increased risk of pancreatic cancer $(\mathrm{OR}=1.72,95 \% \mathrm{Cl} 1.05-2.83 ; P$-interaction $=0.154)$. CONCLUSION: On the basis of these results, circulating levels of components of the IGF axis do not appear to be the risk factors for pancreatic cancer. However, on the basis of the results of a subanalysis, it cannot be excluded that a relatively large amount of IGF-I together with very low levels of IGFBP-3 might still be associated with an increase in pancreatic cancer risk.

British Journal of Cancer (2012) I 06, 1004-1010. doi:I0.1038/bjc.2012.19 www.bjcancer.com

Published online 7 February 2012

(C) 2012 Cancer Research UK

Keywords: IGF-I; IGFBP-3; pancreatic cancer; cohort study

*Correspondence: Dr S Rohrmann; E-mail sabine.rohrmann@ifspm.uzh.ch

Received 20 October 20 I ; revised 12 January 2012; accepted 12 January 20 I2; published online 7 February 2012 
Pancreatic cancer is one of the most common causes of cancer deaths in the western world. In Europe, 48300 deaths in men and 46900 deaths in women due to pancreas cancer were estimated for 2008 (Ferlay et al, 2010). So far, only few risk factors for pancreatic cancer have been clearly identified. Smoking is the major established lifestyle factor known to cause pancreatic cancer, accounting for up to $25-30 \%$ of all pancreas cancer cases (Lowenfels and Maisonneuve, 2004). Some nutrition-related factors have also been found to be associated with pancreas cancer risk, including excess body weight (Berrington de Gonzalez et al, 2003; Jiao et al, 2010), history of type-2 diabetes mellitus (Huxley et al, 2005), elevated blood levels of glucose (Gapstur et al, 2000; Batty et al, 2004; Jee et al, 2005; Stolzenberg-Solomon et al, 2005; Stattin et al, 2007; Grote et al, 2011), and possibly, chronic hyperinsulinemia (Stolzenberg-Solomon et al, 2005).

Insulin-like growth factors (IGFs) are multifunctional peptides that regulate cell proliferation, differentiation, and apoptosis (Khandwala et al, 2000). IGF-I is an important regulator of cell growth in the postnatal period (Khandwala et al, 2000). IGF-binding proteins (IGFBP-1 through IGFBP-6) modulate the biological effects of IGF-I, as they determine the concentration of biologically active, unbound IGF (Jones and Clemmons, 1995). More than $90 \%$ of circulating IGF-I is bound to IGFBP-3, and less than $1 \%$ circulates in free form (Grimberg and Cohen, 2000). Binding of IGF-I to the IGF-I receptor leads to stimulation of mitogenesis in a number of cell types, to cellular protection from apoptosis, and to cellular transformation (Grimberg and Cohen, 2000). IGFBP-3 has growth-inhibiting properties by competitively binding IGF-I, but it also has independent growth inhibiting effects, for example, via induction of apoptosis (Rajah et al, 1997, 2002). IGFBP activities are, among others, regulated by IGFBP proteases, which may cleave IGFBPs into fragments with lower affinity to IGFs (Nunn et al, 1997).

Ohmura et al (1990) have shown that IGF-I can stimulate pancreatic cancer cell growth in vitro, and that this effect is mediated by the IGF-I receptor (Bergmann et al, 1995). The analysis of pancreatic cancer tissue revealed increased IGF-I mRNA and IGF-I receptor mRNA levels, compared with tissue of healthy individuals (Bergmann et al, 1995). Similarly, increased levels of IGF-I and increased IGF-I receptor expression were observed in pancreatic cancer tissue compared with normal pancreas tissue (Karna et al, 2002). It appears that IGF-I stimulation and subsequent suppression of tumour suppressor chromosome 10 (PTEN) activity enhance invasiveness and proliferation of the pancreatic cancer cells (Ma et al, 2010).

Circulating levels of IGF-1- and IGF-binding proteins have been found to be associated with several types of cancers, including colon (Rinaldi et al, 2010), prostate (Roddam et al, 2008), and breast cancer (The Endogenous Hormones and Breast Cancer Collaborative Group, 2010). However, the number of studies conducted with respect to pancreatic cancer is limited, as is the number of cases in these studies. The results of the prospective studies are rather inconsistent, however, with most studies showing no association of circulating IGF-I or IGFBP-3 levels with pancreatic cancer risk (Lin et al, 2004; Stolzenberg-Solomon et al, 2004; Wolpin et al, 2007; Douglas et al, 2010). Because of the inconsistencies of previous studies, we examined the association between IGF-I, IGFBP-3, and pancreatic cancer in the prospective European Prospective Investigation into Cancer and Nutrition (EPIC) cohort, including more than 400 incident cases of pancreatic cancer.

\section{MATERIAL AND METHODS}

\section{Study description}

European Prospective Investigation into Cancer and Nutrition is a prospective cohort study that includes more than 500000 male and female participants recruited in 23 centres in 10 European countries between 1992 and 2000. Most centres recruited subjects from the general population, but in Utrecht and Florence, only women from breast cancer screening programs were recruited; the Spanish and Italian centres include blood donors, and the French cohort consists of members of a health insurance for state school employees. A high proportion of participants of the Oxford cohort are vegetarians or health-conscious volunteers. The cohorts of France, Utrecht, Florence, and Norway include women only.

Information on lifestyle and diet was collected during baseline examination. Diet was assessed using country-specific, validated dietary assessment instruments (Kaaks et al, 1997; Riboli and Kaaks, 1997). Information on smoking, alcohol consumption, physical activity, education, occupation, and medical and reproductive history was collected using questionnaires and personal interviews. Anthropometric measurements was conducted during the baseline examination (Haftenberger et al, 2002).

Following a standardized protocol, a blood sample of $30 \mathrm{ml}$ was collected in all participating EPIC countries. In all centres except Oxford, blood samples were stored protected from light at $5-10^{\circ} \mathrm{C}$ until further processing and aliquoting. In the Oxford centre, blood samples were collected throughout the United Kingdom and transported to the laboratory in Norfolk by mail at an ambient temperature. In all centres except Denmark and Sweden, $0.5-1.5 \mathrm{ml}$ aliquots of serum, plasma, red blood cells, and buffy coat were filled into plastic straws and stored in liquid nitrogen at $-196^{\circ} \mathrm{C}$. In the Danish centres, $1 \mathrm{ml}$ aliquots were filled into tubes and stored in the vapour phase of liquid nitrogen containers $\left(-150^{\circ} \mathrm{C}\right)$. In Sweden, the samples were stored at $-80^{\circ} \mathrm{C}$.

\section{Selection of case and control subjects}

Pancreatic cancer incidence data were coded according to ICD-10, and included all invasive exocrine pancreatic cancers that were coded as C25 (25.0-25.3, 25.7-25.9). Cases were those EPIC participants who developed pancreatic cancer after their recruitment into the cohort and before the end of the study period. Individuals were excluded when diagnosed with another malignant tumour before the diagnosis of pancreatic cancer, except for nonmelanoma skin cancer, and when no blood specimens were available for analysis. A total of 638 incident cases of pancreatic cancer occurred until December 2006; 578 of them were primary exocrine pancreatic tumours. Blood specimens were available for 422 of these cases. The included 422 pancreatic cancer cases were similar in their characteristics to the overall 578 cases with pancreatic adenocarcinoma (data not shown). Of the 422 cases, 307 (76\%) were microscopically confirmed. The remaining $24 \%$ were diagnosed by clinical symptoms, imaging results, or physical examination. Forty-one percent of the tumours occurred in the head of the pancreas, followed by body (7\%) and tail (5\%); the rest of the tumours were of unknown localization. One control, alive and free of cancer at time of diagnosis of the index case, was selected for each case using incidence density sampling, that is, controls may include subjects who became a case later in time, and each control may be sampled more than once. Cases and controls were matched by study centre, sex, age at enrolment ( \pm 6 months), date of entry in the cohort, time between blood sampling and time of last consumption of foods and drinks $(<3 \mathrm{~h}, 3-6 \mathrm{~h},>6 \mathrm{~h})$.

\section{Laboratory assays}

Serum IGF-I and IGFBP-3 concentrations were measured in the immunoassay laboratory at the German Cancer Research Center (DKFZ), Heidelberg, Germany. Both peptides were analysed by enzyme-linked immunosorbent assays purchased from Beckman Coulter (Webster, TX, USA). Before the total IGF-I analysis, IGF-I was separated from IGF-I-binding proteins by an acid-ethanol extraction step. Cases and matched controls were measured in 
singleton within the same batch. Each analytical batch further included three different serum quality control samples. Laboratory staff were blinded to the case/control status of the study samples. Intra-batch and inter-batch coefficients of variation for IGF-I and IGFBP-3 were 12.8 and $12.9 \%$, and 6.5 and $7.2 \%$, respectively.

\section{Statistical analysis}

Conditional logistic regression was used to examine the associations of IGF-I and IGFBP-3 concentrations with pancreatic cancer risk. We also computed the molar ratio of IGF-I to IGFBP-3 (IGF-I/ IGFBP-3 ratio) as a marker of the estimated level of IGF-I biologically available to bind to its receptor. Concentrations of IGF-I and IGFBP-3, as well as IGF-I/IGFBP-3 ratio were categorized into sex-specific quartiles, based on the distribution among all controls. Crude models took into account matching criteria; multivariate models were additionally adjusted for body mass index (continuous), smoking history (never, former, quitting smoking less than 10 years ago, more than 10 years ago, current, with 1-9, $10-19$, or $\geqslant 20$ cigarettes per day, missing), and history of diabetes (self-reported or high glycated haemoglobin (HbAlc) concentration $(\geqslant 6.5 \%))$. These covariates were added in the multivariable adjusted models, because they were associated with pancreatic cancer, correlated with IGF-1 or IGFBP-3, or changed the logistic $\beta$-estimate by more than $10 \%$. Further adjustment was made for circulating C-peptide concentration, which has been measured previously on the same subjects (Grote et al, 2011). Further analyses were conducted with mutual adjustments between IGF-I and IGFBP-3 concentrations.

Sub-analyses were performed, stratified by sex, smoking status at baseline (smoker/non-smoker), diabetes (defined by self-report or HbAlc concentrations $(\geqslant 6.5 \%)$, waist circumference $(</ \geqslant$ median; $96 \mathrm{~cm}$ for men and $80 \mathrm{~cm}$ for women), length of follow-up ( $\leqslant />2$ year of follow-up time in cases), concentration of C-peptide ( $</ \geqslant$ median, $\left.5.57 \mathrm{ng} \mathrm{ml}^{-1}\right)$, and microscopical verification of cases. Odds ratios (OR) were estimated for quartiles of IGF-1 and IGFBP-3 concentrations, as well as IGF-I/IGFBP-3 ratio. Additionally, we examined the interaction between IGF-I and IGFBP-3 levels (both variables were dichotomized by median concentration) in a cross-classification. Statistical tests for heterogeneity were based on $\chi^{2}$-statistics, calculated as the deviations of logistic beta-coefficients observed in each of the subgroups, relative to the overall beta-coefficient. All analyses were conducted with SAS version 9.2 (Cary, NC, USA).

\section{RESULTS}

Of the 422 cases in this analysis, $46 \%$ were men (Table 1). Mean age at baseline was 58 years; mean age at diagnosis was 63 years. Female cases had a higher body mass index and waist circumference than female controls, but no difference was observed among men. Cases were more often smokers at baseline than controls, and they more often reported a diagnosis of diabetes at baseline or had elevated baseline blood levels of HbA1c. IGF-1 was not statistically significantly correlated with body mass index (Pearson's partial correlation coefficient; adjusted for age, sex, and study centre; $r=-0.07$ ( $95 \%$ confidence intervals (CI) -0.17 to $0.03)$ ), waist circumference $(r=-0.03$ (95\% CI -0.13 to 0.08$)$ ), or circulating C-peptide level ( $r=0.10$ (95\% CI -0.005 to 0.20$)$ ), and rather weakly with height $(r=0.11$ (95\% CI 0.010 .21$)$ ), whereas IGFBP-3 showed correlations with body mass index $(r=0.12(95 \%$ CI 0.01 to 0.22$)$ ), waist circumference $(r=0.13$ (95\% CI 0.030 .23$)$ ), and C-peptide levels $(r=0.20$ (95\% CI 0.100 .30$)$ ), but not with height $(r=0.01 \quad(95 \%$ CI -0.09 to 0.12$))$. IGF-1 correlated highly and significantly with IGFBP-3 $(r=0.52(95 \%$ CI 0.44 $0.59)$ ) and the molar IGF-1/IGFBP-3 ratio ( $r=0.78$ (95\% CI 0.74 $0.82)$ ), whereas the ratio showed no correlation with IGFBP-3 $(r=-0.09(95 \%$ CI -0.19 to 0.01$))$.
Table I Baseline characteristics of pancreatic cancer cases and matched controls

\begin{tabular}{|c|c|c|}
\hline Variable & $\begin{array}{c}\text { Cases } \\
(n=422)\end{array}$ & $\begin{array}{l}\text { Controls } \\
(n=422)\end{array}$ \\
\hline Male subjects, $\mathrm{n}(\%)$ & $195(46)$ & $195(46)$ \\
\hline Age at recruitment (y), mean (range) & $58(30-76)$ & $58(30-76$ \\
\hline Age at diagnosis (y), mean (range) & $63(37-82)$ & - \\
\hline Follow-up (y), mean (range) & $5.4(0-13)$ & \\
\hline \multicolumn{3}{|l|}{ BMl $\left(\mathrm{kg} \mathrm{m}^{-2}\right)$, mean \pm s.d. } \\
\hline Male & $26.88 \pm 3.6$ & $26.7 \pm 3.7$ \\
\hline Female & $26.5 \pm 4.9$ & $25.2 \pm 4.2$ \\
\hline \multicolumn{3}{|l|}{ Height $(\mathrm{cm})$, mean \pm s.d. } \\
\hline Male & $174.6 \pm 7.4$ & $175.1 \pm 7.7$ \\
\hline Female & $162.3 \pm 6.6$ & $161.5 \pm 7.2$ \\
\hline \multicolumn{3}{|l|}{ Waist circumference $(\mathrm{cm})$, mean \pm s.d. } \\
\hline Male & $96.2 \pm 10.1$ & $96.6 \pm 10.3$ \\
\hline Female & $84.3 \pm 12.3$ & $81.1 \pm 10.6$ \\
\hline \multicolumn{3}{|l|}{ Smoking status, $\mathrm{n}(\%)^{\mathrm{a}}$} \\
\hline Never & $155(37)$ & $189(45)$ \\
\hline Former & $130(31)$ & $137(32)$ \\
\hline Current & $132(3 \mid)$ & $91(22)$ \\
\hline \multicolumn{3}{|l|}{ Education, n (\%) ${ }^{\mathrm{a}}$} \\
\hline Primary school or less & $165(40)$ & $158(39)$ \\
\hline University & $82(20)$ & $86(21)$ \\
\hline \multicolumn{3}{|l|}{ Physical activity, $n(\%)^{a}$} \\
\hline Active & $62(16)$ & $60(16)$ \\
\hline Inactive & $103(27)$ & $119(31)$ \\
\hline \multicolumn{3}{|c|}{ Alcohol intake at recruitment (g per day), mean \pm s.d. } \\
\hline Male & $19.7 \pm 24.4$ & $20.4 \pm 26.2$ \\
\hline Female & $9.1 \pm 13.1$ & $7.4 \pm 10.6$ \\
\hline \multicolumn{3}{|l|}{ Fasting status, n (\%) } \\
\hline Fasting $(\geqslant 6 h)$ & $117(28)$ & $113(27)$ \\
\hline In between $(3-6 h)$ & $158(37)$ & $163(39)$ \\
\hline Non-fasting $(<3 \mathrm{~h})$ & $66(16)$ & $66(15)$ \\
\hline Unknown & $81(19)$ & $80(19)$ \\
\hline Self-reported diabetes at recruitment, $\mathrm{n}$ (\%) & $30(7)$ & $17(4)$ \\
\hline Subjects $\mathrm{HbAI} \mathrm{c} \geqslant 6.5 \%, \mathrm{n}(\%)$ & $50(12)$ & $28(7)$ \\
\hline C-peptide $\left(\mathrm{ng} \mathrm{ml}^{-1}\right)$, mean \pm s.d. & $6.98 \pm 4.6$ & $6.66 \pm 4.5$ \\
\hline IGF-I $\left(\mathrm{ng} \mathrm{ml}^{-1}\right)$, mean \pm s.d. & $184.8 \pm 71.3$ & $182.5 \pm 68.5$ \\
\hline Male & $187.1 \pm 74.1$ & $185.7 \pm 68.3$ \\
\hline Female & $182.9 \pm 68.9$ & $179.7 \pm 68.7$ \\
\hline IGFBP-3 $\left(n g \mathrm{ml}^{-1}\right)$, mean \pm s.d. & $4668 \pm 1209$ & $4665 \pm 1085$ \\
\hline Male & $4411 \pm 1267$ & $4484 \pm 1042$ \\
\hline Female & $4890 \pm 1114$ & $4821 \pm 1100$ \\
\hline IGF-I/IGFBP-3 ratio & $0.19 \pm 0.06$ & $0.18 \pm 0.06$ \\
\hline
\end{tabular}

Abbreviations: BMI = body mass index; IGF = insulin-like growth factor; IGFBP = IGF-

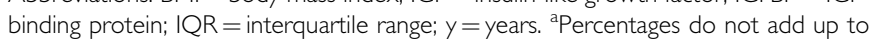
$100 \%$, because not all subgroups are shown.

Circulating levels of IGF-I or IGFBP-3 were not related to the risk of pancreatic cancer (Table 2). Using molar IGF-I/IGFBP-3 ratio as an indicator of free IGF-I concentration, we also observed no association with pancreatic cancer risk. The results were only slightly affected by different types of adjustment. Additional mutual adjustment of IGF-I and IGFBP-3 also did not strongly change the observed associations with pancreatic cancer. There were also no associations of IGF-I, IGFBP-3, or the ratio of these two with pancreatic cancer, when using only microscopically confirmed cases (Table 3).

In sub-analyses, we examined whether the association of IGF-I, IGFBP-3, or IGF-I/IGFBP-3 with pancreatic cancer was modified 
Table 2 Relative risk (OR $(95 \% \mathrm{Cl})$ ) of pancreatic cancer by quartiles of IGF-I, IGFBP-3, and its ratio in EPIC

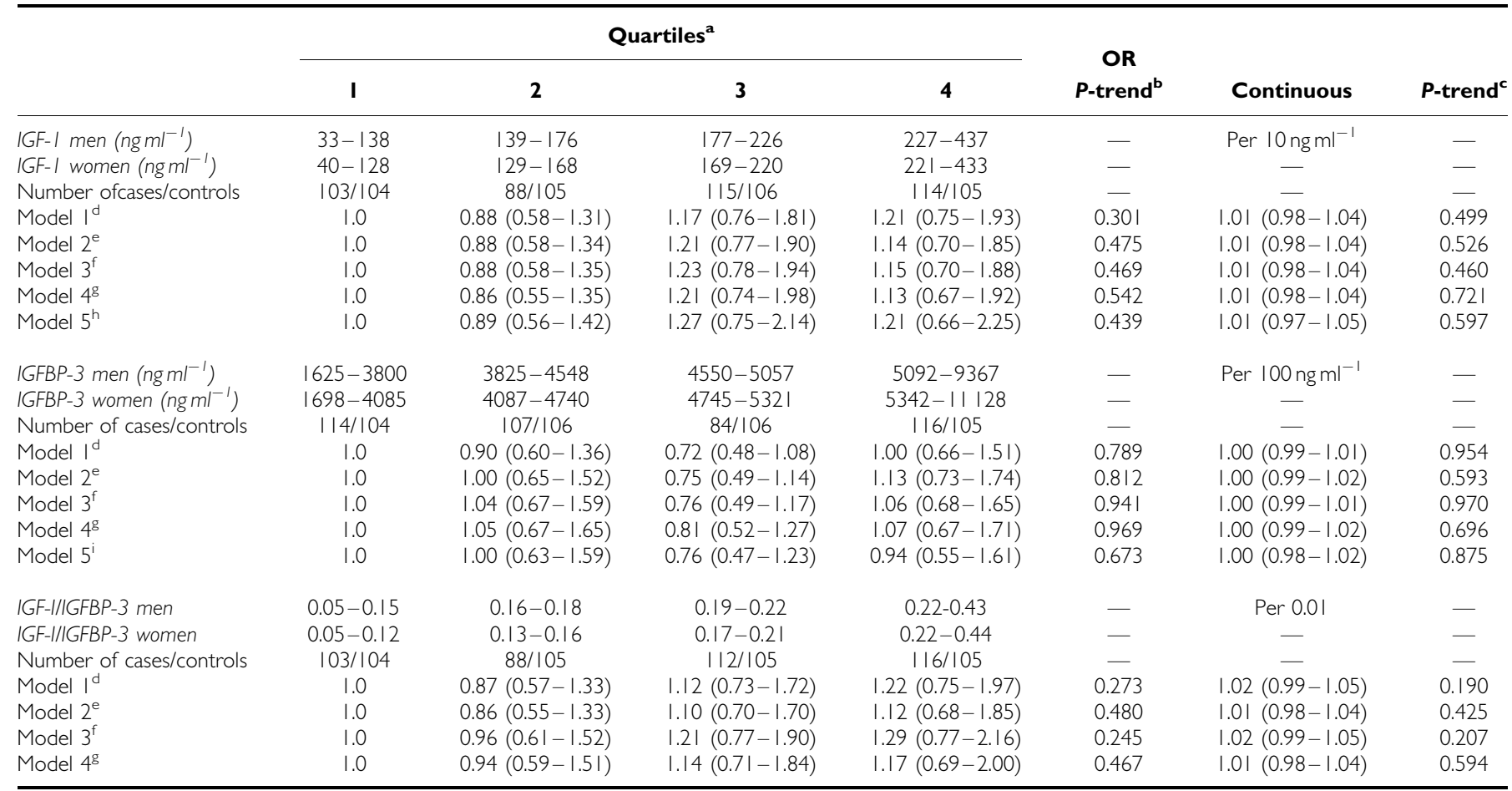

Abbreviations: $\mathrm{BMI}=$ body mass index; $\mathrm{Cl}=$ confidence interval; $\mathrm{EPIC}=$ European Prospective Investigation into Cancer and Nutrition; IGF=insulin-like growth factor; IGFBP = IGF-binding protein; OR = odds ratio. ${ }^{a}$ Quartile cut points were based on the distribution of controls. ${ }^{b}$-trend test was based on median values of each quartile. ${ }^{C} P$-trend test was based on continuous values. 'Model I: logistic regression conditioned on matching factors (EPIC recruitment centre, sex, age at recruitment, date at entry in the cohort, time between blood sampling and last consumption of foods and drinks). ${ }^{~}$ Model 2: as model I with further adjustment for smoking (never, former, quitting smoking less

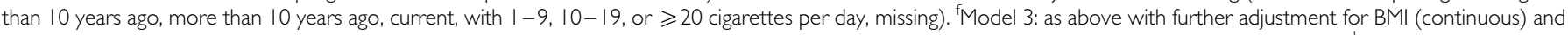
diabetes (defined by self-report or $\mathrm{HbAl}$ c concentration $\geqslant 6.5 \%$ ). ${ }^{\mathrm{g}}$ Model 4: as above with further adjustment for $\mathrm{C}$-peptide concentration (continuous). ${ }^{\mathrm{h}}$ Model 5 : as above with further adjustment for IGFBP-3 concentration (continuous). 'Model 5: as model 3 with further adjustment for IGF-I concentration (continuous).

by sex, smoking status, length of follow-up, waist circumference, diabetes status, or circulating C-peptide concentration (Table 3). With few exceptions, we did not observe statistically significant heterogeneity between subgroups. Waist circumference modified the association of IGF-1 and IGF-1/IGFBP-3 ratio with pancreatic cancer risk, such that IGF-1 concentration were positively associated with pancreatic cancer in subjects with low waist circumference when comparing quartile 3 with quartile 1 ; no association was observed when comparing the top $v s$ the bottom quartile. There were no statistically significant associations among individuals with waist circumference above the median.

We cross-classified the IGF-I and IGFBP-3 concentration and observed an increased risk of pancreatic cancer among those with IGF-I concentration above the median and IGFBP-3 concentration below the median $(\mathrm{OR}=1.72,95 \% \mathrm{CI} 1.05-2.83)$; however, the test for interaction was not statistically significant $(P=0.154$; Table 4$)$.

\section{DISCUSSION}

We examined the association of components of the IGF axis in association with the risk of pancreatic cancer in the largest prospective study, so far without finding any indication for an association with the circulating levels of IGF-I and IGFBP-3. There was, however, an increased risk among those with high IGF-I and concurrently low IGFBP-3 concentrations, although the interaction was not statistically significant. Evans et al (1997) found no elevated serum levels of IGF-I and IGFBP-3 in pancreatic cancer compared with controls. In contrast, Karna et al (2002) showed significant increases in serum IGF-I and IGFBP-3 levels in patients with pancreatic cancer compared with control subjects. Among prospective studies, a case-control study nested within the ATBC trial did not observe associations of serum concentrations of IGF-1, IGFBP-3, or IGF-1/IGFBP-3 ratio with the risk of pancreatic cancer (Stolzenberg-Solomon et al, 2004); however, this result is based on a cohort of male smokers only. This null association, though, is similar to the results seen in the four US cohorts that were analysed together (Wolpin et al, 2007). Only a nested casecontrol study conducted in Japan reported that individuals in the highest quartile of IGF-I concentration had an OR of 2.31 (95\% CI $0.70-2.64)$ compared with participants in the lowest quartile (Lin et al, 2004). A recently published study nested in the PLCO cohort observed an increased risk of pancreatic cancer with increasing IGF-I/IGFBP-3 molar ratio, which was interpreted as an indicator of the concentration of free IGF-I (Douglas et al, 2010). We did not observe an increase in risk with increasing IGF-I/IGFBP-3 molar ratio, but did observe that those participants with high IGF-I levels above the median and low IGFBP-3 concentrations had an increased risk of pancreatic cancer.

IGFBP-3 is supposed to have growth-inhibiting properties and one would, thus, expect that high IGFBP-3 concentrations are inversely associated with cancer risk. On the other hand, IGFBP-3 and IGF-I are highly correlated in our cohort. In the Japanese nested case-control study, IGFBP-3 concentration was positively associated with pancreatic cancer risk; the risk of death from pancreatic cancer was increased with increasing levels of serum IGFBP-3, with the OR for the highest quartile being $2.53(95 \%$ $\mathrm{CI}=0.93-6.85$; Lin et al, 2004). However, the results of previous studies on different types of cancer have been inconsistent with some studies indeed showing inverse associations, but some also showing no or even a positive association (Renehan et al, 2004). Cleavage of IGFBPs by proteases results in IGFBP fragments with lower affinity to IGFs and additionally influences IGF-I bioavailability by reducing the amount of functional IGFBPs. It has been 
Table 3 Relative risk (OR $(95 \% \mathrm{Cl})$ ) of pancreatic cancer by quartiles of IGF-I, IGFBP-3, and its ratio for subgroups in EPIC

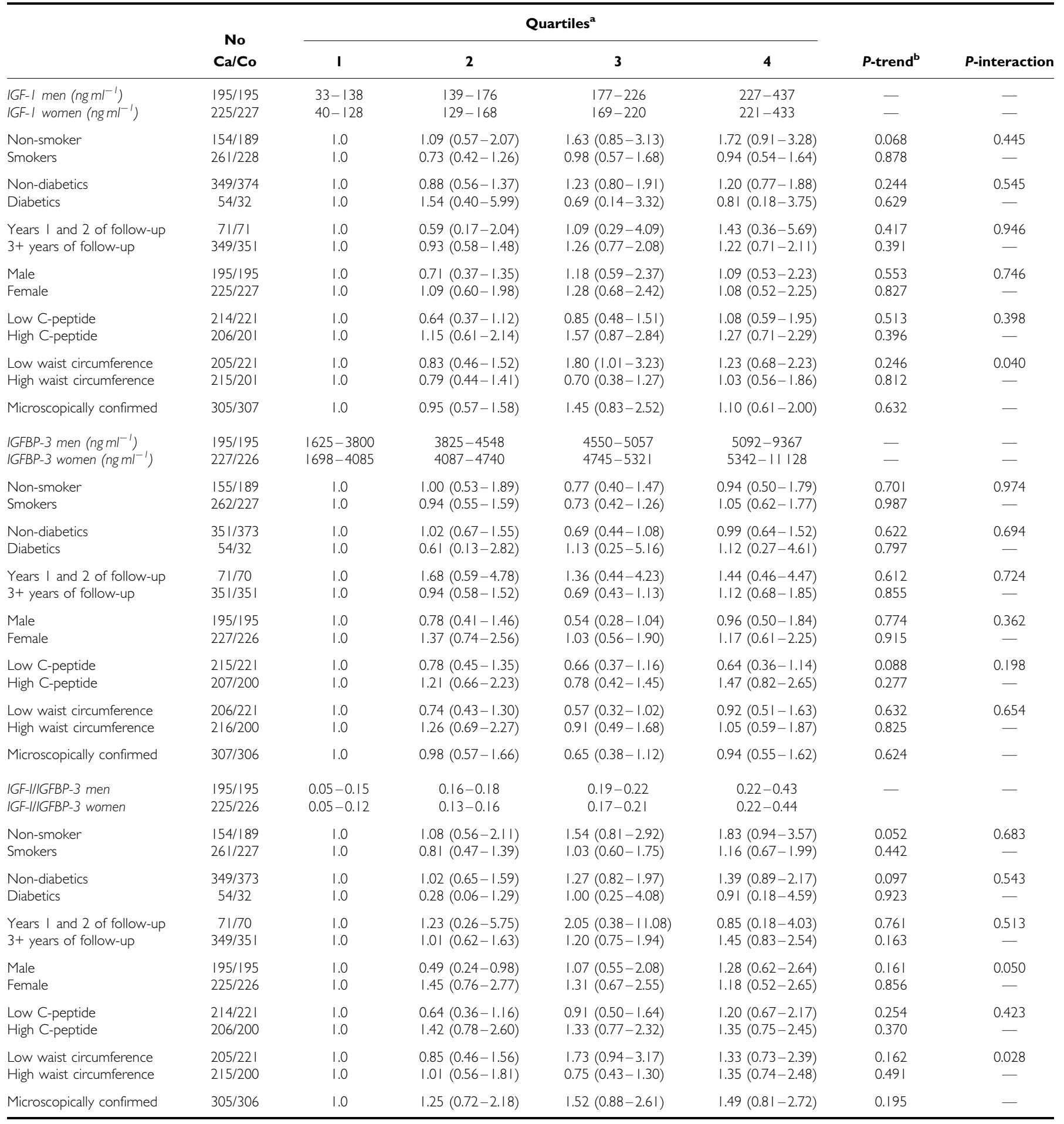

Abbreviations: $\mathrm{BMI}=$ body mass index; $\mathrm{Cl}=$ confidence interval; $\mathrm{EPIC}=$ European Prospective Investigation into Cancer and Nutrition; IGF=insulin-like growth factor; IGFBP = IGF-binding protein; OR = odds ratio. 'Logistic regression conditioned on matching factors (EPIC recruitment centre, sex, age at recruitment, date at entry in the cohort, time between blood sampling and last consumption of foods and drinks) and adjusted for smoking (never, former, quitting smoking less than 10 years ago, more than 10 years ago, current, with $1-9,10-19$, or $\geqslant 20$ cigarettes per day, missing), BMI (continuous) and diabetes (defined by self-report or HbAlc concentrations $\geqslant 6.5 \%$ ). ${ }^{b} P$-trend test was based on median values of each quartile.

suggested that the maintenance of normal IGFBP levels is critical to normal rates of cell growth and cell death (Nunn et al, 1997; Firth and Baxter, 2002). It has also been discussed that different assays measuring concentrations of total or intact IGFBP-3 could cause differences between studies (Kaaks et al, 2001; Renehan et al, 2004; Rinaldi et al, 2005). We measured intact IGFBP-3, not total
IGFBP-3, which also includes IGFBP-3 fragments that are less biologically active.

Most IGF-I in the circulation is produced by the liver (Pollak et al, 2004). A major factor stimulating the hepatic production of IGF-I and IGFBP-3 is growth hormone (Jones and Clemmons, 1995), but insulin also has a central role in regulating levels of 
Table 4 Joint effect of IGF-I and IGFBP-3 concentrations on risk of pancreatic cancer $(\mathrm{OR}(95 \% \mathrm{Cl}))^{\mathrm{a}, \mathrm{b}}$

\begin{tabular}{lcc}
\hline & $<$ Median IGF-I & $\geqslant$ Median IGF-I \\
\hline$\geqslant$ Median IGFBP-3 & 1.0 & $1.48(0.97-2.22)$ \\
$<$ Median IGFBP-3 & $1.47(0.97-2.22)$ & $1.72(1.05-2.83)$ \\
\hline
\end{tabular}

Abbreviations: $\mathrm{BMI}=$ body mass index; $\mathrm{Cl}=$ confidence interval; $\mathrm{EPIC}=$ European Prospective Investigation into Cancer and Nutrition; IGF = insulin-like growth factor;

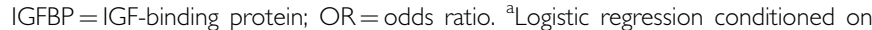
matching factors (EPIC recruitment centre, sex, age at recruitment, date at entry in the cohort, time between blood sampling and last consumption of foods and drinks) and adjusted for smoking (never, former, quitting smoking less than 10 years ago, more than 10 years ago, current, with $1-9,10-19$, or $\geqslant 20$ cigarettes per day, missing), BMI (continuous) and diabetes (defined by self-report or $\mathrm{HbAlc}$

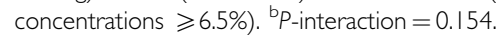

IGF-I and IGFBPs. For example, insulin increases the hepatic levels of growth hormone receptors, thereby enhancing liver synthesis of IGF-I, and in addition, insulin increases bioactivity of IGF-I by inhibiting the synthesis of IGFBP-1 (Lee et al, 1997; Kaaks and Lukanova, 2001). Therefore, we stratified our analysis by circulating $\mathrm{C}$-peptide concentration to evaluate whether the association between IGF-1 and IGFBP-3, and pancreatic cancer was different in individuals with high or low C-peptide levels. However, we observed no statistically significant interaction, which is similar to what Wolpin et al (2007) had observed in their analysis. We also examined whether other factors that are either well-known risk factors for pancreatic cancer or are associated with IGF-I concentration modified the effect of IGF-I or IGFBP-3 on pancreatic cancer risk. However, none of the factors examined modified the observed association. We only observed statistically significant interactions of waist circumference with levels of IGF-I or IGF-I/IGFBP-3 ratio, but the associations in the respective subgroups were not consistently statistically significant.

In the EPIC cohort, only one blood sample has been collected at baseline. It might be that repeated measurements of IGF-I and IGFBP-3 more accurately reflect circulating levels at different points in time. However, single serum measurements of IGF-I and IGFBP-3 generally have been found to be quite representative of serum concentrations over longer time periods. In a study within the New York University Women's Health Study cohort, Spearman's rank correlations between repeat measurements in serum samples collected over time periods of more than 1 year were 0.87 and 0.73 , respectively, for IGF-I and IGFBP-3 (Lukanova et al, 2004). Other research groups have reported similar levels of reproducibility for circulating IGF-I and IGFBP-3 (GoodmanGruen and Barrett-Connor, 1997; Chan et al, 1998).

In conclusion, our results generally do not support the hypothesis that circulating levels of IGF-1 and IGFBP-3, or the molar IGF-I/ IGFBP-3 ratio are associated with the risk of pancreatic cancer, which confirms the results of most previous prospective studies. However, it is noteworthy that individuals with high circulating IGF-I and low IGFBP-3 levels have an increased risk of pancreatic cancer, compared with those with low IGF-I and high IGFBP-3 concentrations.

\section{ACKNOWLEDGEMENTS}

We thank Miss Britta Lederer and Miss Sigrid Henke for their excellent work in performing the immunoassays. VAG is funded by the Deutsche Forschungsgemeinschaft, Graduiertenkolleg 793. The coordination of the EPIC is financially supported by the European Commission (DG-SANCO) and the International Agency for Research on Cancer. The national cohorts are supported by the Danish Cancer Society (Denmark); LigueContre le Cancer, InstitutGustaveRoussy, MutuelleGénérale de l'EducationNationale, Institut National de la Santé et de la RechercheMédicale (INSERM; France); Deutsche Krebshilfe, Deutsches Krebsforschungszentrum (DKFZ), and the Federal Ministry of Education and Research (Germany); Ministry of Health and Social Solidarity, Stavros Niarchos Foundation, and Hellenic Health Foundation (Greece); Italian Association for Research on Cancer (AIRC) and National Research Council (Italy); Dutch Ministry of Public Health, Welfare and Sports (VWS), the Netherlands Cancer Registry (NKR), LK Research Funds, Dutch Prevention Funds, Dutch ZON (ZorgOnderzoek Nederland), World Cancer Research Fund (WCRF), Statistics Netherlands (The Netherlands); ERC-2009-AdG 232997 and Nordforsk, Nordic Centre of Excellence Programme on Food, Nutrition and Health (Norway); Health Research Fund (FIS), Regional Governments of Andalucía, Asturias, Basque Country, Murcia and Navarra, ISCIII RETIC (RD06/0020; Spain); Swedish Cancer Society, Swedish Scientific Council and Regional Government of Skåne and Västerbotten (Sweden); Cancer Research UK, Medical Research Council, Stroke Association, British Heart Foundation, Department of Health, Food Standards Agency, and Wellcome Trust (United Kingdom).

\section{REFERENCES}

Batty GD, Shipley MJ, Marmot M, Smith GD (2004) Diabetes status and post-load plasma glucose concentration in relation to site-specific cancer mortality: findings from the original Whitehall study. Cancer Causes Control 15: 873-881

Bergmann U, Funatomi H, Yokoyama M, Beger HG, Korc M (1995) Insulinlike growth factor I overexpression in human pancreatic cancer: evidence for autocrine and paracrine roles. Cancer Res 55: 2007-2011

Berrington de Gonzalez A, Sweetland S, Spencer E (2003) A metaanalysis of obesity and the risk of pancreatic cancer. Br J Cancer 89: $519-523$

Chan JM, Stampfer MJ, Giovannucci E, Gann PH, Ma J, Wilkinson P, Hennekens CH, Pollak M (1998) Plasma insulin-like growth factor-I and prostate cancer risk: a prospective study. Science 279: 563-566

Douglas JB, Silverman DT, Pollak MN, Tao Y, Soliman AS, StolzenbergSolomon RZ (2010) Serum IGF-I, IGF-II, IGFBP-3, and IGF-I/IGFBP-3 molar ratio and risk of pancreatic cancer in the prostate, lung, colorectal, and ovarian cancer screening trial. Cancer Epidemiol Biomarkers Prev 19: $2298-2306$

Evans JD, Eggo MC, Donovan IA, Bramhall SR, Neoptolemos JP (1997) Serum levels of insulin-like growth factors (IGF-I and IGF-II) and their binding protein (IGFBP-3) are not elevated in pancreatic cancer. Int $J$ Pancreatol 22: $95-100$
Ferlay J, Parkin DM, Steliarova-Foucher E (2010) Estimates of cancer incidence and mortality in Europe in 2008. Eur J Cancer 46: 765-781

Firth SM, Baxter RC (2002) Cellular actions of the insulin-like growth factor binding proteins. Endocr Rev 23: 824-854

Gapstur SM, Gann PH, Lowe W, Liu K, Colangelo L, Dyer A (2000) Abnormal Glucose Metabolism and Pancreatic Cancer Mortality. JAMA 283: $2552-2558$

Goodman-Gruen D, Barrett-Connor E (1997) Epidemiology of insulin-like growth factor-I in elderly men and women. The Rancho Bernardo Study. Am J Epidemiol 145: 970 - 976

Grimberg A, Cohen P (2000) Role of insulin-like growth factors and their binding proteins in growth control and carcinogenesis. J Cell Physiol 183: $1-9$

Grote VA, Rohrmann S, Nieters A, Dossus L, Tjonneland A, Halkjaer J, Overvad K, Fagherazzi G, Boutron-Ruault MC, Morois S, Teucher B, Becker S, Sluik D, Boeing H, Trichopoulou A, Lagiou P, Trichopoulos D, Palli D, Pala V, Tumino R, Vineis P, Panico S, Rodriguez L, Duell EJ, MolinaMontes E, Dorronsoro M, Huerta JM, Ardanaz E, Jeurnink SM, Beulens JW, Peeters PH, Sund M, Ye W, Lindkvist B, Johansen D, Khaw KT, Wareham $\mathrm{N}$, Allen N, Crowe F, Jenab M, Romieu I, Michaud DS, Riboli E, Romaguera D, Bueno-de-Mesquita HB, Kaaks R (2011) Diabetes mellitus, glycated haemoglobin and C-peptide levels in relation to pancreatic cancer risk: a 
study within the European Prospective Investigation into Cancer and Nutrition (EPIC) cohort. Diabetologia 54: 3037-3046

Haftenberger M, Lahmann PH, Panico S, Gonzalez CA, Seidell JC, Boeing $\mathrm{H}$, Giurdanella MC, Krogh V, Bueno-de-Mesquita HB, Peeters PH, Skeie G, Hjartaker A, Rodriguez M, Quiros JR, Berglund G, Janlert U, Khaw KT, Spencer EA, Overvad K, Tjonneland A, Clavel-Chapelon F, Tehard B, Miller AB, Klipstein-Grobusch K, Benetou V, Kiriazi G, Riboli E, Slimani $\mathrm{N}$ (2002) Overweight, obesity and fat distribution in 50- to 64-year-old participants in the European Prospective Investigation into Cancer and Nutrition (EPIC). Public Health Nutr 5: 1147-1162

Huxley R, Ansary-Moghaddam A, Berrington de Gonzalez A, Barzi F, Woodward M (2005) Type-II diabetes and pancreatic cancer: a metaanalysis of 36 studies. Br J Cancer 92: 2076-2083

Jee SH, Ohrr H, Sull JW, Yun JE, Ji M, Samet JM (2005) Fasting serum glucose level and cancer risk in Korean men and women. JAMA 293: 194-202

Jiao L, Berrington de Gonzalez A, Hartge P, Pfeiffer R, Park Y, Freedman D, Gail M, Alavanja M, Albanes D, Beane Freeman L, Chow W-H, Huang W-Y, Hayes R, Hoppin J, Ji B-t, Leitzmann M, Linet M, Meinhold C, Schairer C, Schatzkin A, Virtamo J, Weinstein S, Zheng W, StolzenbergSolomon R (2010) Body mass index, effect modifiers, and risk of pancreatic cancer: a pooled study of seven prospective cohorts. Cancer Causes Control 21: $1305-1314$

Jones JI, Clemmons DR (1995) Insulin-like growth factors and their binding proteins: biological actions. Endocr Rev 16: 3-34

Kaaks R, Lukanova A (2001) Energy balance and cancer: the role of insulin and insulin-like growth factor-I. Proc Nutr Soc 60: 91-106

Kaaks R, Rinaldi S, Lukanova A, Akhmedkhanov A, Zeleniuch-Jacquotte A, Toniolo P (2001) Correspondence re: Giovannucci et al., A prospective study of plasma insulin-like growth factor-1 and binding protein-3 and risk of colorectal neoplasia in women. Cancer Epidemiol Biomark Prev 9: 345-349, 2000; Cancer Epidemiol Biomark Prev 10: 1103-1104

Kaaks R, Slimani N, Riboli E (1997) Pilot phase studies on the accuracy of dietary intake measurements in the EPIC project: overall evaluation of results. European Prospective Investigation into Cancer and Nutrition. Int J Epidemiol 26(Suppl 1): S26-S36

Karna E, Surazynski A, Orlowski K, Laszkiewicz J, Puchalski Z, Nawrat P, Palka J (2002) Serum and tissue level of insulin-like growth factor-I (IGF-I) and IGF-I binding proteins as an index of pancreatitis and pancreatic cancer. Int J Exp Pathol 83: 239-246

Khandwala HM, McCutcheon IE, Flyvbjerg A, Friend KE (2000) The effects of insulin-like growth factors on tumorigenesis and neoplastic growth. Endocr Rev 21: 215-244

Lee PD, Giudice LC, Conover CA, Powell DR (1997) Insulin-like growth factor binding protein-1: recent findings and new directions. Proc Soc Exp Biol Med 216: 319-357

Lin Y, Tamakoshi A, Kikuchi S, Yagyu K, Obata Y, Ishibashi T, Kawamura T, Inaba Y, Kurosawa M, Motohashi Y, Ohno Y (2004) Serum insulin-like growth factor-I, insulin-like growth factor binding protein-3, and the risk of pancreatic cancer death. Int J Cancer 110: 584-588

Lowenfels AB, Maisonneuve P (2004) Epidemiology and Prevention of Pancreatic Cancer. Jpn J Clin Oncol 34: 238-244

Lukanova A, Zeleniuch-Jacquotte A, Lundin E, Micheli A, Arslan AA, Rinaldi S, Muti P, Lenner P, Koenig KL, Biessy C, Krogh V, Riboli E, Shore RE, Stattin P, Berrino F, Hallmans G, Toniolo P, Kaaks R (2004) Prediagnostic levels of C-peptide, IGF-I, IGFBP $-1,-2$ and -3 and risk of endometrial cancer. Int I Cancer 108: 262-268

Ma J, Sawai H, Matsuo Y, Ochi N, Yasuda A, Takahashi H, Wakasugi T, Funahashi H, Sato M, Takeyama H (2010) IGF-1 Mediates PTEN Suppression and Enhances Cell Invasion and Proliferation via Activation of the IGF-1/PI3K/Akt Signaling Pathway in Pancreatic Cancer Cells. J Surg Res 160: $90-101$

Nunn SE, Gibson TB, Rajah R, Cohen P (1997) Regulation of prostate cell growth by the insulin-like growth factor binding proteins and their proteases. Endocrine 7: 115-118
Ohmura E, Okada M, Onoda N, Kamiya Y, Murakami H, Tsushima T, Shizume K (1990) Insulin-like growth factor I and transforming growth factor $\mathrm{I} \pm$ as autocrine growth factors in human pancreatic cancer cell growth. Cancer Res 50: $103-107$

Pollak MN, Schernhammer ES, Hankinson SE (2004) Insulin-like growth factors and neoplasia. Nat Rev Cancer 4: 505-518

Rajah R, Lee KW, Cohen P (2002) Insulin-like growth factor binding protein-3 mediates tumor necrosis factor-alpha-induced apoptosis: role of Bcl-2 phosphorylation. Cell Growth Differ 13: 163-171

Rajah R, Valentinis B, Cohen P (1997) Insulin-like growth factor (IGF)binding protein-3 induces apoptosis and mediates the effects of transforming growth factor-betal on programmed cell death through a p53- and IGF-independent mechanism. J Biol Chem 272: 12181-12188

Renehan AG, Zwahlen M, Minder C, O'Dwyer ST, Shalet SM, Egger M (2004) Insulin-like growth factor (IGF)-I, IGF binding protein-3, and cancer risk: systematic review and meta-regression analysis. Lancet 363: $1346-1353$

Riboli E, Kaaks R (1997) The EPIC Project: rationale and study design. European Prospective Investigation into Cancer and Nutrition. Int $J$ Epidemiol 26(Suppl 1): S6-S14

Rinaldi S, Cleveland R, Norat T, Biessy C, Rohrmann S, Linseisen J, Boeing H, Pischon T, Panico S, Agnoli C, Palli D, Tumino R, Vineis P, Peeters $\mathrm{PH}$, van Gils $\mathrm{CH}$, Bueno-de-Mesquita BH, Vrieling A, Allen NE, Roddam A, Bingham S, Khaw KT, Manjer J, Borgquist S, Dumeaux V, Torhild Gram I, Lund E, Trichopoulou A, Makrygiannis G, Benetou V, Molina E, Donate Suarez I, Barricarte Gurrea A, Gonzalez CA, Tormo MJ, Altzibar JM, Olsen A, Tjonneland A, Gronbaek H, Overvad K, Clavel-Chapelon F, Boutron-Ruault MC, Morois S, Slimani N, Boffetta P, Jenab M, Riboli E, Kaaks R (2010) Serum levels of IGF-I, IGFBP-3 and colorectal cancer risk: results from the EPIC cohort, plus a meta-analysis of prospective studies. Int J Cancer 126: $1702-1715$

Rinaldi S, Kaaks R, Zeleniuch-Jacquotte A, Arslan AA, Shore RE, Koenig KL, Dossus L, Riboli E, Stattin P, Lukanova A, Toniolo P (2005) Insulinlike growth factor-I, IGF binding protein-3, and breast cancer in young women: a comparison of risk estimates using different peptide assays. Cancer Epidemiol Biomarkers Prev 14: 48-52

Roddam AW, Allen NE, Appleby P, Key TJ, Ferrucci L, Carter HB, Metter EJ, Chen C, Weiss NS, Fitzpatrick A, Hsing AW, Lacey Jr JV., Helzlsouer K, Rinaldi S, Riboli E, Kaaks R, Janssen JA, Wildhagen MF, Schroder FH, Platz EA, Pollak M, Giovannucci E, Schaefer C, Quesenberry Jr CP, Vogelman JH, Severi G, English DR, Giles GG Stattin P, Hallmans G, Johansson M, Chan JM, Gann P, Oliver SE, Holly JM, Donovan J, Meyer F, Bairati I, Galan P (2008) Insulin-like growth factors, their binding proteins, and prostate cancer risk: analysis of individual patient data from 12 prospective studies. Ann Intern Med 149: 461 - 471, W83-W88

Stattin P, Björ O, Ferrari P, Lukanova A, Lenner P, Lindahl B, Hallmans G, Kaaks R (2007) Prospective study on hyperglycemia and cancer risk. Diabetes Care 30: $561-567$

Stolzenberg-Solomon RZ, Graubard BI, Chari S, Limburg P, Taylor PR, Virtamo J, Albanes D (2005) Insulin, Glucose, Insulin Resistance, and Pancreatic Cancer in Male Smokers. JAMA 294: 2872-2878

Stolzenberg-Solomon RZ, Limburg P, Pollak M, Taylor PR, Virtamo J, Albanes D (2004) Insulin-like growth factor (IGF)-1, IGF-binding protein-3, and pancreatic cancer in male smokers. Cancer Epidemiol Biomarkers Prev 13: $438-444$

The Endogenous Hormones and Breast Cancer Collaborative Group (2010) Insulin-like growth factor 1 (IGF1), IGF binding protein 3 (IGFBP3), and breast cancer risk: pooled individual data analysis of 17 prospective studies. Lancet Oncol 11: 530-542

Wolpin BM, Michaud DS, Giovannucci EL, Schernhammer ES, Stampfer MJ, Manson JE, Cochrane BB, Rohan TE, Ma J, Pollak MN, Fuchs CS (2007) Circulating insulin-like growth factor axis and the risk of pancreatic cancer in four prospective cohorts. $\mathrm{Br} J$ Cancer 97: $98-104$

This work is published under the standard license to publish agreement. After 12 months the work will become freely available and the license terms will switch to a Creative Commons Attribution-NonCommercial-Share Alike 3.0 Unported License. 